\title{
DOMESTIC Rhodnius ecuadoriensis (HEMIPTERA, REDUVIIDAE) INFESTATION IN NORTHERN PERU: A COMPARATIVE TRIAL OF DETECTION METHODS DURING A SIX-MONTH FOLLOW-UP
}

\author{
César Augusto CUBA CUBA(1), Franklin VARGAS(2), Judith ROLDAN(2) \& Cynthia AMPUERO(2)
}

\begin{abstract}
SUMMARY
Two passive methods in the assessment of intradomiciliary infestation by Rhodnius ecuadoriensis were tested: (i) the Gomes Nuñez sensor box (GN), (ii) sheets of white typing paper and (iii) one active timed manual method. The study was carried out in the Alto Chicama River Valley, Province of Gran Chimú, Department of La Libertad. The study design consisted of an initial searching of triatomines inside of the domestic environment by the manual capture active procedure (man/hour) covering all the studied houses. Then, matched pairs of GN boxes and paper sheets were simultaneously installed in the bedrooms of 207 households distributed in 19 localities. A comparative prospective trial of these passive detection devices were monitored at 2, 4 and, finally 6 months follow-up. Parasitological Trypanosoma rangeli and/or T. cruzi infections were investigated in two houses with high level of infestation by $R$. ecuadoriensis.

$16.9 \%$ of the 207 households investigated by an initial active manual method were infested with R. ecuadoriensis. The proportion of infested houses fluctuated from 6.2 to $55.5 \%$ amongst the 19 localities investigated. $T$. rangeli natural infection was detected in $R$. ecuadoriensis specimens collected in two households. Parasite rates in the bugs ranged from 16.6 to $21.7 \%$ respectively. The most striking fact was an average rate of salivary gland infection ranging from 7.4 to $8.3 \%$. At the end of the sixth month period, a cumulative incidence of $31.4 \%$ of positive GN boxes against $15.9 \%$ for paper sheets was recorded. All three methods combined detected domestic infestation in $129(62.3 \%)$ of the 207 houses studied in the 19 localities. The range of houses infested varies from $6.7 \%$ to $92.9 \%$. In areas with low bug density infestation rates, the methodology experienced in our studies, seems to be the best choice for investigations on domestic $R$. ecuadoriensis populations.
\end{abstract}

KEYWORDS: Triatominae; Rhodnius ecuadoriensis; Detection methods; Domestic populations; Peru.

\section{INTRODUCTION}

Trypanosoma cruzi and Trypanosoma rangeli transmission in the western and eastern regions of Northern Peru was previously documented many years ago ${ }^{6,18}$ and Chagas disease has been frequently reported since the 1950s up to now ${ }^{30}$. The main vector of American Trypanosomiasis in the Western Amazonian slopes of the Andes (Selva Alta) is Panstrongylus herreri, Wygodzinsky, 1948. The only proved vector of T. rangeli is Rhodnius ecuadoriensis.

The situation in the northern Pacific watersheds and valleys remains uncertain and complicated mainly because 16 species of triatomines were registered as prevalent in the region ${ }^{8}$. At present, triatominae species found naturally infected by T. cruzi are: P. herreri, Panstrongylus chinai, Triatoma carrioni, Rhodnius robustus, Rhodnius pictipes and $R$. ecuadoriensis, the latter also infected with $T$. rangeli. Furthermore, $T$. rangeli in some parts of Northern Peru is present in the same vectors and reservoir hosts of $T$. cruzi. T. rangeli is said to be non-pathogenic to humans but may confuse diagnosis of Chagas disease if it is detected by parasitological examination (xenodiagnosis) and by conventional serology 14,15

Although Peru has joined the Southern Cone Program against Chagas Disease with a view to eliminate Triatoma infestans from the southern endemic region (Southern Cone Commission, 1997), there is no formal activity against the disease in northern Peru. The lack of epidemiological information on human infection rates and ecological and biogeographical documentation of the vectors and reservoirs hampers the implementation of control strategies.

Gómez Nuñez sensors have been adopted in studies on domestic infestation by T. infestans s $^{12,17,27,31}$; Rhodnius prolixus ${ }^{13,28}$ and Panstrongylus megistus $^{22}$. However, there are no previous studies in the literature on the performance of passive detection methods focusing on domiciliated

Partially supported by CNPq and CAPES, Brazil. Ministerio de la Salud, MINSA, Perú; Instituto Nacional de Salud, INS/MINSA and ECLAT

(1) Universidade de Brasilia, Faculdade de Medicina, Brasilia, Brasil.

(2) Universidad de Trujillo, Facultad de Ciencias Biológicas, Perú.

Correspondence to: César A. Cuba Cuba, Faculdade de Medicina, Universidade de Brasilia, 70910-900 Brasilia, DF, Brasil. 


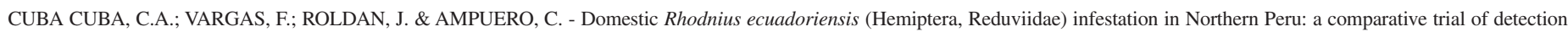
methods during a six-month follow-up. Rev. Inst. Med. trop. S. Paulo, 45(2):85-90, 2003.

infestation by $R$. ecuadoriensis. The present report aims at comparing the applicability and sensitivity of three sampling methods namely: sensor boxes: Gómez Núñez, paper-sheets and man/hour capture in the process of detecting domestic invasion of $R$. ecuadoriensis in localities with low bug infestation rates.

\section{MATERIAL AND METHODS}

The study area: The study was carried out in 19 localities (caseríos) situated in the Province of Gran Chimú, Department of La Libertad, Peru. The area is located at the transverse valleys of Rivers Cascas and Alto Chicama that cross the eastern slopes of the Andes forming the Pacific watersheds (approximately $7^{\circ} 22^{\prime} \mathrm{S} ; 7^{\circ} 57^{\prime} \mathrm{W}$ ) (Fig 1). The altitudinal distribution of $R$. ecuadoriensis in this area ranges from 450 to 850 meters above sea level. Annual rainfall varied between 0 to 12 $\mathrm{mm} /$ year in 1998 and 0 to $7.5 \mathrm{~mm}$ in 1999. The last six months of the year are always very dry. Monthly maximum temperature ranged from 26 to $28{ }^{\circ} \mathrm{C}$ with little variation throughout the period. Microclimatic measurements inside households sampled showed temperature ranging from $28{ }^{\circ} \mathrm{C}$ to $38^{\circ} \mathrm{C}$ and relative humidity from 26 to $36.3 \%$.

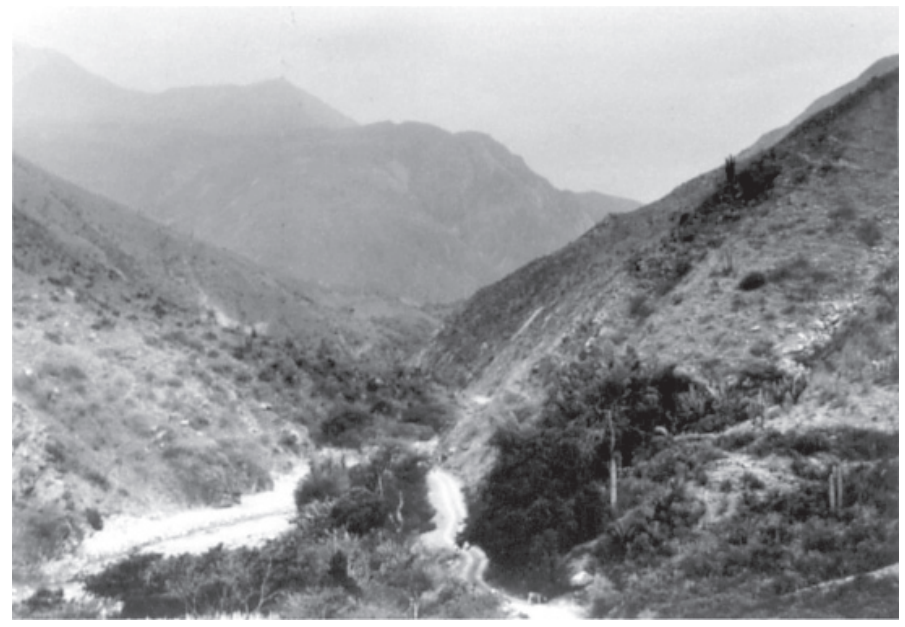

Fig. 1 - Panoramic ecosystem, natural scenary for Rhodnius ecuadoriensis in Alto Chicama Valley in Northern Peruvian Andes (850 m a.s.1.m.).

Baseline studies: Previous entomological studies carried out by ROLDAN $^{24}$ in a representative sample of 259 domiciliary units, in 21 localities (EPIINFO $5.0 \mathrm{p}=5 \%, 95 \%$, expected frequency $=2.5 \%$ ) showed the following basic entomological information: 10 (47.6\%) out of 21 localities sampled presented R. ecuadoriensis signals of infestation. A rate of intradomiciliary infestation of $10 \%$ (26 out of 259 households searched) was determined using the active method of manual capture man/hour collection.

The following entomological indexes were established: dispersion rate $=0.5(10 / 21$ of localities sampled $)$; density $=0.79(204$ insects $/ 259$ households) and crowding rate $=7.8$ (204 insects/26 households). These data suggests a low bug domiciliary infestation area.

The study design: The study consisted of a comparative prospective trial of matched pairs of Gómez Núñez (G.N.) boxes and paper sheets that were installed in 207 households in 19 localities and monitored over a six-month period (Fig. 2). Before installing the sensing devices, two skilled workers spent half hour each searching for living bugs, exuviae's, eggs and faecal streaks of triatomines. The presence of the last three products was registered and considered as a sign of positive infestation. Subsequently to finding positive and/or negative dwellings, matched pairs of G.N. boxes and papers were placed on the walls of the bedrooms of each household surveyed ${ }^{20}$ (Fig. 3). The team visited the households periodically ( 2, 4 and 6 months after the first visit) checking the sensing devices for the presence or not of bugs and their products. The householders were instructed on the aims of this study and when the sensors fell down or were damaged, they were replaced. Faecal streaks on paper sheets and boxes were labelled to avoid further recording.

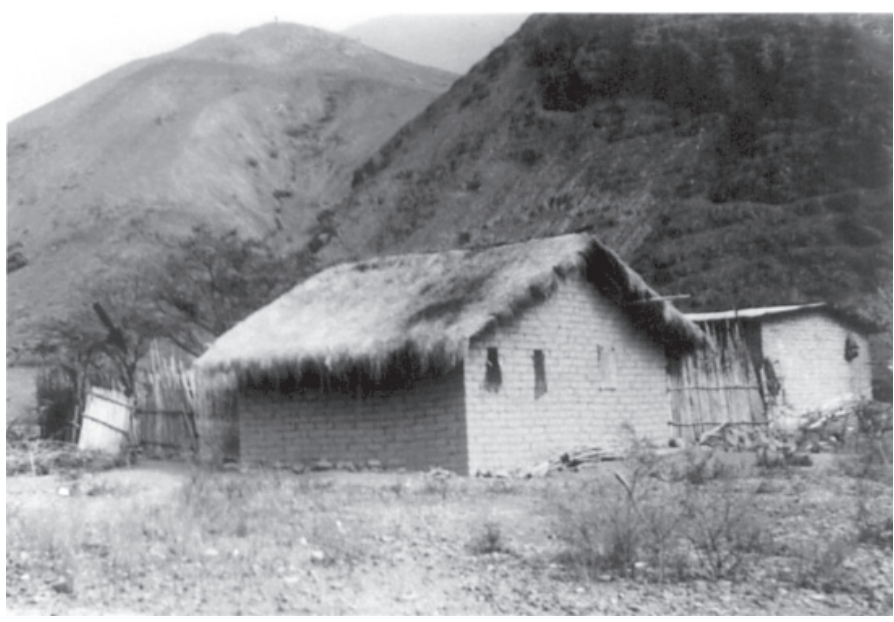

Fig. 2 - Typical example of household infested with Rhodnius ecuadoriensis: note the roof built with rice straw and non-plastered clay-bricks ("adobes") walls. At the peridomicile, an Cavia porcellus corral built with cane and clay ("quincha")- an ecotope for the specie.

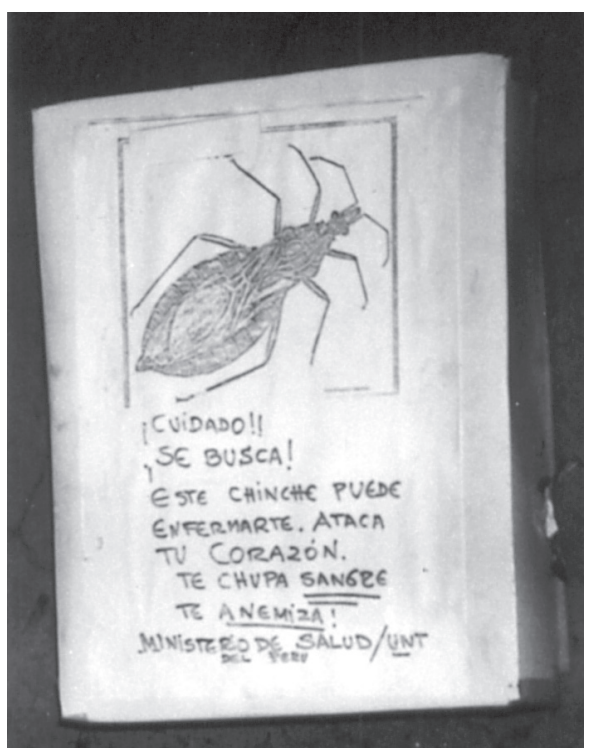

Fig. 3 - Gómez Núñez Box, sensor placed vertically over the bed. A warning notice was placed on the sensor informing on the danger of the triatomines ("chirimachas"). 
In two houses harbouring heavy infestations, the bugs collected were counted and identified according to developmental stage, in order to establish the age structure associated with Trypanosomatidae infection. Parasitological techniques for primary isolation of trypanosomes, cryopreservation and biological identification were carried out according to CUBA CUBA ${ }^{7}$. A statistical analysis was carried out with the Student's $t$ test of means comparison $(p<0.05)$. The best estimate of intradomiciliary infestation for each method was obtained selecting the highest number of positive houses detected in each of the nineteen localities. The Spearman correlation was applied at the level of $\mathrm{p}<0.01$.

\section{RESULTS}

Table 1 shows the results of infested households determined by each sampling method at the end of the six-month period. The active method of manual capture, carried out in the initial phase of the survey, found $16.9 \%$ infested households. The percentage of infested households by this procedure ranged from 6.2 to $55.5 \%$ in the nineteen localities studied.

The comparative analysis of the performance of the two passive detection methods proved that Gomez Nuñez boxes (G.N.) detected

Table 1

Comparison of the sensitivity between active and passive methods in the detection of domestic populations of Rhodnius ecuadoriensis. Results observed in 207 houses from 19 localities. Province of Gran Chimú - Department of La Libertad - Peru (2000 - 2001$)$

\begin{tabular}{|c|c|c|c|c|c|c|c|c|c|c|c|c|c|c|}
\hline \multirow{5}{*}{ Localities } & \multirow{5}{*}{$\begin{array}{c}\mathrm{N}^{\circ} \text { of } \\
\text { Houses }\end{array}$} & \multicolumn{13}{|c|}{ Triatominae detection methods used } \\
\hline & & \multirow{2}{*}{\multicolumn{2}{|c|}{$\begin{array}{c}\text { Active } \\
\text { Manual Capture }\end{array}$}} & \multicolumn{11}{|c|}{$\begin{array}{l}\text { Passive sensors } \\
\end{array}$} \\
\hline & & & & \multirow{3}{*}{$\begin{array}{c}\mathrm{N}^{\circ} \text { of } \\
\text { Sensors } \\
\text { Installed }\end{array}$} & \multirow{2}{*}{\multicolumn{5}{|c|}{$\begin{array}{l}\text { Gómez - Núñez Boxes } \\
\text { Positive Units }\end{array}$}} & \multirow{2}{*}{\multicolumn{5}{|c|}{$\begin{array}{l}\text { Sheet of Paper } \\
\text { Positive Units }\end{array}$}} \\
\hline & & \multirow{2}{*}{$\begin{array}{c}\mathrm{N}^{\mathrm{o}} . \\
\text { Positives }\end{array}$} & \multirow{2}{*}{$\%$} & & & & & & & & & & & \\
\hline & & & & & $2 \mathrm{~m}$ & $4 \mathrm{~m}$ & $6 \mathrm{~m}$ & $\mathrm{~N}^{\circ} .+$ & $\%$ & $2 \mathrm{~m}$ & $4 \mathrm{~m}$ & $6 \mathrm{~m}$ & $\mathrm{~N}^{\circ} .+$ & $\%$ \\
\hline 1) $\mathrm{Mol}$ & 6 & 0 & 0 & 6 & 0 & 0 & 0 & 0 & 0 & 0 & 0 & 0 & 0 & 0 \\
\hline 2) Pan & 6 & 0 & 0 & 6 & 0 & 0 & 0 & 0 & 0 & 0 & 0 & 0 & 0 & 0 \\
\hline 3) Hua & 5 & 0 & 0 & 5 & 0 & 0 & 0 & 0 & 0 & 0 & 0 & 0 & 0 & 0 \\
\hline 4) Zap & 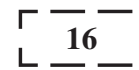 & 1 & $\overline{6.2}\rfloor$ & 16 & 0 & 0 & 0 & 0 & 0 & 0 & 0 & 0 & 0 & 0 \\
\hline 5) $\mathrm{Cue}$ & 13 & 4 & 30.7 & 13 & 2 & 1 & 2 & 5 & 38.5 & 0 & 2 & 0 & 2 & 15.4 \\
\hline 6) Cor & 19 & 3 & 15.7 & 19 & 1 & 2 & 1 & 4 & 21 & 2 & 0 & 2 & 4 & 21 \\
\hline 7) T. P. & 14 & 5 & 35.7 & 14 & 10 & 2 & 1 & 13 & 92.9 & 4 & 1 & 1 & 6 & 42.9 \\
\hline 8) Pam & 11 & 0 & 0 & 11 & 0 & 0 & 0 & 0 & 0 & 0 & $\overline{0}$ & 1 & 1 & 8 \\
\hline 9) S. A. & 14 & 0 & 0 & 14 & 1 & 2 & 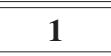 & 4 & 28.6 & 0 & 0 & 0 & 0 & 0 \\
\hline 10) $\mathrm{Mv}$. & 15 & 2 & 13.3 & 15 & 5 & 1 & 3 & 9 & 60 & 2 & 3 & 0 & 5 & 33 \\
\hline 11) Co. & 9 & 5 & 55.5 & 9 & 4 & 3 & 1 & 8 & 88.8 & 3 & 1 & 1 & 5 & 55.5 \\
\hline 12) P. C & 15 & 1 & 6.6 & 15 & 0 & 0 & 2 & 2 & 13 & 0 & 1 & 0 & 1 & 6.7 \\
\hline 13) C. B. & 12 & 1 & 8.3 & 12 & 1 & 0 & 2 & 3 & 25 & 0 & 0 & 0 & 0 & 0 \\
\hline 14) Hig & 10 & 2 & 20 & 10 & 0 & 1 & 1 & 2 & 20 & 0 & 0 & 0 & 0 & 0 \\
\hline 15) Lap & $\ulcorner-8$ & 1 & $\overline{12.5}$ & 8 & 0 & 0 & 0 & 0 & 0 & 0 & 0 & 0 & 0 & 0 \\
\hline 16) $\mathrm{Cie}$ & 8 & 6 & 75 & 8 & 1 & 3 & 1 & 5 & 62.5 & 0 & 1 & 0 & 1 & 12.8 \\
\hline 17) $\mathrm{Bch}$ & 8 & 4 & 50 & 8 & 1 & 4 & 2 & 7 & 87.5 & 2 & 2 & 0 & 4 & 50 \\
\hline 18) P. L. & 8 & 0 & 0 & 8 & 1 & 0 & 1 & 2 & 25 & 1 & 1 & 1 & 3 & 37.5 \\
\hline 19) Poz & 10 & 0 & 0 & 10 & n.d. & 0 & 0 & 1 & 10 & 0 & 1 & 0 & 1 & 10 \\
\hline TOTAL & 207 & 35 & 16.9 & 207 & $\begin{array}{l}27 \\
(13)\end{array}$ & $\begin{array}{c}19 \\
(10.5)\end{array}$ & $\begin{array}{c}19 \\
(11.8)\end{array}$ & 65 & 31.4 & $\begin{array}{c}14 \\
(7.8)\end{array}$ & $\begin{array}{c}13 \\
(6.7)\end{array}$ & $\begin{array}{c}6 \\
(3.3)\end{array}$ & 33 & 15.9 \\
\hline
\end{tabular}

$\ulcorner\neg$ Detected only by Manual Capture

\llcorner\lrcorner (exuvias, eggs corion)

Detected only by Gomez-Nuñez Box 


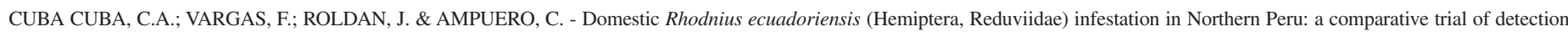
methods during a six-month follow-up. Rev. Inst. Med. trop. S. Paulo, 45(2):85-90, 2003.

almost twice as many signals of $R$. ecuadoriensis intradomiciliary infestation than paper-sheets. As demonstrated, G.N. showed a cumulative incidence of $31.4 \%$ while paper-sheets showed only $15.9 \%$ at the end of the six-month period. The G.N. sensors best performance in detection of triatomines was further confirmed analyzing the correlation between the estimated number of infested houses in each locality and infestation by each method (G.N. boxes: $r=0.9902, n=16, p<0.01$; paper sheets: $\mathrm{r}=0.7468, \mathrm{n}=16, \mathrm{p}<0.01$; active capture: $\mathrm{r}=0.7318, \mathrm{n}=16, \mathrm{p}<0.01$ ). The percentage of infested households detected by G.N. sensors varied from $10 \%$ to $92.9 \%$. In relation to sensitivity, similar results were found for both paper sheets and the active timed manual method.

Each method alone detected infestation in a different household and locality, where the other failed to detect. The active method of manual capture was able to detect one infested household out of 16 surveyed in Zapotal and one out of eight in Lapalen. G.N. boxes detected four infested households out of 14 in Santa Ana. Paper sheet detected one infested household out of 11 in Pampa Larga.

All three methods combined detected domestic infestation in 129 (62.3\%) of the 207 households studied in the 19 localities.

As expected, paper sheets were more easily lost or damaged: By the $2^{\text {nd }}$ month, $7.2 \%$ were lost; the $4^{\text {th }}$ month, $15.9 \%$ and at the end of the $6^{\text {th }}$ month, $17.8 \%$. In contrast, G.N. box losses were: $0 \% ; 3.4 \%$ and $4 \%$, respectively (results not shown). We assume these losses of both devices irrelevant for the analysis because they were systematically replaced.

Tables 2 and 3 show the frequency of $T$. rangeli natural infection in R. ecuadoriensis, manually collected and examined in the two infested households. A noteworthy feature was the infection rate of salivary glands: $8.3 \%$ in one household with bug infestation rate of $16.6 \%$ and $7.4 \%$ in another with bug infestation rate of $21.7 \%$. This is the first time

Table 2

Frequency of Trypanosoma rangeli natural infection from Rhodnius ecuadoriensis" collected at one infested house and examined according to the bug age composition and biology of parasitism. Alto Chicama Valley, La Libertad, Peru

\begin{tabular}{lcccccc}
\hline & \multicolumn{5}{c}{ Insect system examined } \\
\cline { 2 - 7 } Triatominae Instar & \multicolumn{2}{c}{$\begin{array}{l}\text { Intestine } \\
\text { (Faeces) }\end{array}$} & Haemolymph & \multicolumn{2}{c}{$\begin{array}{c}\text { Salivary } \\
\text { Glands }\end{array}$} \\
& + & - & + & - & + & - \\
\hline Nymph I & 0 & 2 & 0 & 2 & 0 & 2 \\
Nymph II & 0 & 9 & 0 & 9 & 0 & 9 \\
Nymph III & 0 & 4 & 0 & 4 & 0 & 4 \\
Nymph IV & 1 & 4 & 1 & 4 & 1 & 4 \\
Nymph V & 0 & 0 & 0 & 0 & 0 & 0 \\
Male & 2 & 1 & 2 & 1 & 0 & 3 \\
Female & 1 & 0 & 0 & 3 & 1 & 0 \\
\hline Total: N ${ }^{\text {o Nymphs }}$ & 1 & 19 & 1 & 19 & 1 & 19 \\
Adults & 3 & 1 & 2 & $4 *$ & 1 & 3 \\
$\%+$ & 16.6 & & 11.5 & & 8.3 & \\
\hline
\end{tabular}

*Man/hour intradomiciliary collection in House P3. Infection rate:16.6\%; Salivary Glands infection rate: $8.3 \%$; **Two adults examined only in Haemolymph: negatives that the natural salivary glands infection rates for $R$. ecuadoriensis are recorded. T. cruzi infections were not recorded in any insects examined.

\section{DISCUSSION}

Systematic measurements of basic factors on ecology, mapping of geographical distribution and epidemiology of Chagas disease vectors in Northern Peru are lacking. Limited or absent is also the information about the biology and potentiality as vectors of $T$. cruzi and/or T. rangeli.

R. ecuadoriensis colonizes human environments in northern Peru ${ }^{8}$ and southern areas of Ecuador where it is a significant Chagas disease vector $^{3,4}$. Sylvatic populations breed in Phytelephas aequatorialis palm trees in subtropical valleys of Pichincha, Ecuador ${ }^{1,2,25}$.

R. ecuadoriensis has a natural preference for a dry and xerophytic ecosystem, which is commonly seen in Northern Peru. No palm trees exist throughout their recognized dispersion areas. Early observations carried out by CUBA CUBA et al. ${ }^{6}$ in localities of Cajamarca and La Libertad established the concept that $R$. ecuadoriensis had a successful adaptation to domestic habitats, based on the insect behaviour and an anecdotic householders accounts, that this triatomine has been there long before the investigations cited above. At the present time, this assumption proves to be true by the fact that persistent dwelling infestation remains along all these years, due surely to a lack of comprehensive and systematic control implementation. ROLDAN ${ }^{24}$, adopting the routine active method of manual capture man/hour, described a relatively low intradomiciliary infestation rate of $10 \%$ in the same region of Alto Chicama Valley, La Libertad, Peru, subject of our ongoing studies, partially presented in this report.

The presence of $R$. ecuadoriensis inside of bedrooms, kitchens and deposits is described by the inhabitants in such a way that reflects total

Table 3

Frequency of Trypanosoma rangeli natural infection from Rhodnius ecuadoriensis ${ }^{*}$ collected at one infested house and examined according to the bug age composition and biology of parasitism. Alto Chicama Valley, La Libertad, Peru

\begin{tabular}{|c|c|c|c|c|c|c|}
\hline \multirow{3}{*}{ Triatominae Instar } & \multicolumn{6}{|c|}{ Insect system examined } \\
\hline & \multicolumn{2}{|c|}{$\begin{array}{l}\text { Intestine } \\
\text { (Faeces) }\end{array}$} & \multicolumn{2}{|c|}{ Haemolymph } & \multicolumn{2}{|c|}{$\begin{array}{c}\text { Salivary } \\
\text { Glands }\end{array}$} \\
\hline & + & - & + & - & + & - \\
\hline Nymph I & 0 & 0 & 0 & 0 & 0 & 0 \\
\hline Nymph II & 0 & 9 & 0 & 9 & 0 & 9 \\
\hline Nymph III & 0 & 8 & 1 & 7 & 1 & 7 \\
\hline Nymph IV & 0 & 3 & 0 & 3 & 0 & 3 \\
\hline Nymph V & 1 & 2 & 4 & 0 & 1 & 2 \\
\hline Male & 0 & 4 & 1 & 3 & 0 & 4 \\
\hline Female & 0 & 0 & 0 & 0 & 0 & 0 \\
\hline Total No. Nymphs & 1 & 22 & 5 & 19 & 2 & 21 \\
\hline Adults & 0 & 4 & 1 & 3 & 0 & 4 \\
\hline$\%+$ & \multicolumn{2}{|c|}{3.7} & \multicolumn{2}{|c|}{21.4} & \multicolumn{2}{|c|}{7.4} \\
\hline
\end{tabular}

* Man/Hour intradomiciliary collection in House P1. Infection rate: $21.7 \%$; Salivary Glands infection rate: $7.4 \%$. One nymph examined only in haemolymph (+). 


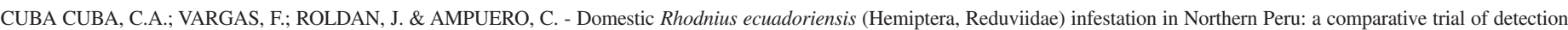
methods during a six-month follow-up. Rev. Inst. Med. trop. S. Paulo, 45(2):85-90, 2003.

acquaintance with the species. Regrettable is the indoors breeding, under beds and inside the kitchen, of Cavia porcellus, guinea-pigs ("cuyes"), an ancient habitual practice of rural Peruvian Andean inhabitants. These rodents, clearly are source of feeding for the triatomines and colonies of $R$. ecuadoriensis are frequently associated with these highly synantropic animals.

Peridomiciliary habitats have been shown by some workers as chicken nests and piles of mud brick ${ }^{5}$. HERRER et al..$^{18}$ recorded $R$. ecuadoriensis in two localities: one placed in the Pacific watersheds (Huarmaca Valley, Department of Piura at 450 m.a.s.1.) and the other, at the Atlantic watersheds (Huancabamba Valley, at 1,200 m.a.s.1.). They found the species both in intradomiciliary and in sylvatic ecotopes (hole of Schinus molle). In spite of these observations the existence of sylvatic populations of $R$. ecuadoriensis in Peru remains to be confirmed. Recently PATTERSON et al..$^{21}$ have shown morphometric differences between sylvatic and domestic populations of $R$. ecuadoriensis from Ecuador and Peru. The latter has important epidemiological implications on control strategies against this triatomine.

Since the original description of GÓMEZ-NÚNEZZ ${ }^{13}$ the box has been used by several workers ${ }^{10,12,23}$ in Brazil; SCHENONE et al. ${ }^{26}$ in Chile and GÜRTLER et $a l .{ }^{17}$, WISNIVESKY-COLLI et al. ${ }^{31}$, in Argentina for $T$. infestans. As pointed out elsewhere, contrasting results are observed in the literature when researchers have made comparisons of several active and passive detection methods (GÜRTLER et al. ${ }^{16}$ ). In Venezuela TONN et al. ${ }^{28}$ carried out a research comparing the man/hour method against the Gómez-Núñez box for detection of $R$. prolixus and concluded recommending the manual man/timed method. Other authors reached better results using flushing-out agents and collection of house-dwellers ${ }^{12,17,23}$.

MARSDEN \& PENNA ${ }^{20}$ working in Mambaí, Goiás State, Brazil reported that the Gómez-Núñez sensor is well accepted and better understood in its function than other procedures by the householders, encouraging them to report $T$. infestans. We noticed a good level of acceptance of G.N. boxes amongst the inhabitants of Alto Chicama Valley, reflected by the low number of damaged devices along the period of study.

GAMBOA $^{11}$ was the first to show evidence that the Gómez-Núñez sensor box is particularly useful in detection of Rhodnius prolixus in houses with a low density of insects. The situation seems to be similar to search houses submitted to insecticides intervention. As established elsewhere, the detectability of house infestations increases with the density of bugs ${ }^{16}$. The present field work has been conducted in a region where no control measures have been instituted against triatominae bugs. In our knowledge, there is no information concerning the usefulness of passive detection methods with domiciliated $R$. ecuadoriensis.

Our results in the six-month follow-up are in agreement with the Argentinean experience with $T$. infestans ${ }^{17}$ in which sensor boxes were more sensitive than their matched paper sheets. Gómez-Núñez boxes detected almost two times more $R$. ecuadoriensis than paper sheets and timed manual capture, as previous data from the literature. It is noteworthy the significant increase of bug detection when the methods are applied altogether.

On the other hand, the apparent absence of $T$. cruzi in the area studied should not preclude a future search in other $R$. ecuadoriensis populations where natural infections have been recorded ${ }^{5,18,19}$. The species is the only proved vector of Trypanosoma rangeli in Northern Peru ${ }^{7}$. The average rate of intestinal, haemolymph and salivary gland infections detected is in agreement with those in $R$. prolixus and $R$. pallescens. In $R$. prolixus, natural infection rates of intestine with $T$. rangeli ranged from $2 \%$ to $47 \%$, while infection of haemolymph and salivary glands was found in $1 \%$ to $15 \%$. Field research on reservoirs and natural human infections is strongly recommended. As discussed elsewhere serological and parasitological diagnosis of T. cruzi infection in human, vectors and reservoirs is complicated when $T$. rangeli is also presented in the same endemic region ${ }^{29}$.

Biogeography and control studies in endemic areas of Peru and Ecuador (where the species is currently distributed) would be feasible using both passive detection devices. Their utility in monitoring house reinfestation/repopulation after insecticide application is being evaluated at present.

\section{RESUMO}

\section{Infestação domiciliar por Rhodnius ecuadoriensis (Hemiptera, Reduviidae): um estudo comparativo de métodos de detecção durante seis meses de seguimento}

A detecção de infestações domiciliares por triatomíneos é fundamental no desenvolvimento de estratégias de controle. Como parte de um estudo amplo sobre triatomíneos vetores de tripanossomatídeos no norte do Peru testamos a aplicação de dois métodos passivos de detecção de infestações intradomiciliares por Rhodnius ecuadoriensis: (i) a caixa de Gómez Núñez (GN) e (ii) folhas de papel. Um método de captura manual também foi empregado. Realizamos o estudo no vale Alto Chicama, Província de Gran Chimú, Departamento de La Liberdad, uma área de baixa infestação domiciliar. A metodologia consistiu inicialmente em procurar ativamente os triatomíneos em todas as casas por captura manual (homem/hora). Posteriormente, instalamos simultaneamente pares de caixas de Gómez Núñez e folhas de papel nos quartos de 207 casas, distribuídas em 19 áreas e monitoradas após dois, quatro e seis meses. A infecção por Trypanosoma rangeli e/ou T. cruzi foi investigada em duas casas com altos índices de infestação por $R$. ecuadoriensis.

16,9\% das 207 casas investigadas pelo método de captura manual estavam infestadas por $R$. ecuadoriensis. A proporção de casas infestadas variou de 6,2 a 55,5\% nas 19 áreas estudadas. A infecção natural por $T$. rangeli foi observada em $R$. ecuadoriensis coletados em duas casas, com taxas de infecção de 16,6 a $21,7 \%$, respectivamente. $O$ fato mais interessante foi a taxa de infecção de glândulas salivares variando de 7,4 a 8,3\%. Após seis meses, quando os resultados da comparação entre os dois métodos passivos foram analisados, obtivemos $31,4 \%$ das caixas de Gomez Nuñez positivas, resultado quase duas vezes superior ao das folhas de papel $(15,9 \%)$. Os três métodos somados detectaram infestação em 129 das 207 casas estudadas $(62,3 \%)$ nas 19 áreas estudadas. O número de casas infestadas variou de $6,7 \%$ a $92,9 \%$. Não observamos diferenças na positividade das folhas de papel e captura manual. Em áreas com baixas taxas de infestação, a metodologia usada neste estudo parece ser a melhor escolha em pesquisas de populações domésticas de R. ecuadoriensis. 


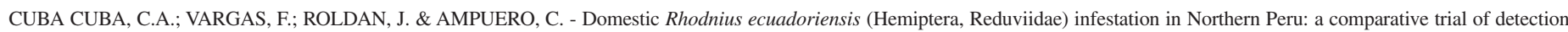
methods during a six-month follow-up. Rev. Inst. Med. trop. S. Paulo, 45(2):85-90, 2003.

\section{REFERENCES}

1. ABAD-FRANCH, F.; NOIREAU, F.; PAUCAR, C.A. et al. - The use of live-bait traps for the study of sylvatic Rhodnius populations (Hemiptera, Reduviidae) in palm trees. Trans. roy. Soc. trop. Med. Hyg., 94: 629-630, 2000.

2. ABAD-FRANCH, F.; PAUCAR, C.A.; CARPIO, C.C. et al. - Biogeography of Triatominae (Hemiptera, Reduviidae) in Ecuador: implications for the design of control strategies. Mem. Inst. Oswaldo Cruz, 96: 611-620, 2001.

3. ABAD-FRANCH, F.; AGUILAR, V.H.M.; PAUCAR, C.A.; LOROSA, E.S. \& NOIREAU, F. - Observations on the domestic ecology of Rhodnius ecuadoriensis (Triatominae). Mem. Inst. Oswaldo Cruz, 97: 199-202, 2002.

4. AGUILAR, V.H.M.; ABAD-FRANCH, F.; RACINES, V.J. \& PAUCAR, C.A. Epidemiology of Chagas disease in Ecuador: a brief review. Mem. Inst. Oswaldo Cruz, 94 (suppl. 1): 387-393, 1999.

5. CASTILLO, R.D. - Rhodnius ecuadoriensis naturalmente infectado por Trypanosoma cruzi en el Valle de Zaña, Lambayeque. In: CONGRESO PERUANO DE PARASITOLOGIA, 2., Trujillo, Peru, 1995.

6. CUBA CUBA, C.A.; MORALES, N.; FERNÁNDEZ, E. \& FERNÁNDEZ, W. -Hallazgo de Rhodnius ecuadoriensis Lent \& León, 1958 infectado naturalmente por trypanosomas semejantes a Trypanosoma rangeli Tejera, 1920 en caseríos del Distrito de Cascas, Contumazá, Dpto. de Cajamarca, Perú. Rev. Inst. Med. trop. S. Paulo, 14: 191-202, 1972.

7. CUBA CUBA, C.A. - Revisión de los aspectos biológicos y diagnósticos del Trypanosoma (Herpetosoma) rangeli. Rev. Soc. bras. Med. trop., 31: 207-220, 1998.

8. CUBA CUBA, C.A.; ABAD-FRANCH, F.; ROLDÁN RODRÍGUEZ, J. et al. - The triatomines of Northern Peru, with emphasis on the ecology and infection by Trypanosomes of Rhodnius ecuadoriensis (Triatominae). Mem. Inst. Oswaldo Cruz, 97: 175-183, 2002

9. D'ALESSANDRO, A. - Biology of Trypanosoma (Herpetosoma) rangeli Tejera, 1920. In: LUMSDEN, W.H.R. \& EVANS, D., ed. Biology of the Kinetoplastida. London, Arnold, 1976. v 1, p. 335-380.

10. FORATTINI, O.P.; RABELLO, E.X.; PATTOLI, D.G. \& CORREA R.R. - Observações sobre a infestação domiciliar residual por Triatoma infestans. Rev. Saúde públ. (S. Paulo), 5: 17-21, 1971.

11. GAMBOA, J. - Comprobación de la presencia de Rhodnius prolixus en la vivienda rural. Bol. Inf. Direcc. Malar., 5: 270-274, 1965.

12. GARCIA-ZAPATA, M.T. - Vigilância epidemiológica no controle do Triatoma infestans em duas áreas no Estado de Goiás-Brasil. Brasilia, 1985. (Disertação de Mestrado Universidade de Brasilia).

13. GÓMEZ-NÚÑEZ, J.C. - Desarrollo de un nuevo método para evaluar la infestación intradomiciliar por Rhodnius prolixus. Acta cient. venez., 16: 26-31, 1965

14. GUHL, F. \& MARINKELLE, C.J. - Antibodies against Trypanosoma cruzi in mice infected with T. rangeli. Ann. trop. Med. Parasit., 76: 361, 1982.

15. GUHL, F.; HUDSON, L.; MARINKELLE, C.J.; JARAMILLO, C.A. \& BRIDGE, D. Clinical Trypanosoma rangeli infection as a complication of Chagas' disease. Parasitology, 94: 475-484, 1987.

16. GÜRTLER, R.E.; CHUIT, R.; CECERE, M.C. \& CASTAÑERA, M.B. -Detecting domestic vectors of Chagas disease: comparative trial of six methods in north-west Argentina. Bull. Wld. Hlth. Org., 73: 487-494, 1995.
17. GÜRTLER, R.E.; CECERE, M.C.; CANALE, D.M. et al. - Monitoring house reinfestation by vectors of Chagas disease: a comparative trial of detection methods during fouryear follow-up. Acta trop. (Basel), 72: 213-234, 1999.

18. HERRER, A.; WYGODZINSKY, P. \& NAPÁN, M. - Presencia del Trypanosoma rangel Tejera, 1920, en el Perú. El insecto vector, Rhodnius ecuadoriensis Lent \& León, 1958. Rev. Biol. trop. (S. José), 20: 141-149, 1972.

19. LLANOS, B. - Hallazgo en el Perú del Rhodnius ecuadoriensis Lent \& León, 1958, naturalmente infectado por el Trypanosoma cruzi. Arch. peru. Pat. Clín., 15: 133140,1961

20. MARSDEN, P.D. \& PENNA, R.A. - A 'vigilance unit' for households subject to triatomine control. Trans. roy. Soc. trop. Med. Hyg., 76: 790-792, 1982.

21. PATTERSON, J.S.; ABAD-FRANCH, F.; CUBA CUBA, C.A. \& MILES, M.A. Morphometric distinction of domestic and sylvatic populations of Rhodnius ecuadoriensis (Triatominae) from different geographical origins. J. bras. Pat., 37 (supl.): 189, 2001.

22. PIESMAN, J. \& SHERLOCK, I.A. - Sensitivity of Gómez-Núñez boxes for the detection of household infestation with Panstrongylus megistus. Rev. Soc. bras. Med. trop., 17: 17-20, 1984

23. PINCHIN, R.; FANARA, D.M.; CASTLETON, C.W. \& OLIVEIRA FILHO, A.M. Comparison of techniques for detection of domestic infestations with Triatoma infestans in Brazil. Trans. roy. Soc. trop. Med. Hyg., 75: 691-694, 1981.

24. ROLDÁN, R.J. - Aspectos ecológicos e índice tripano-triatomino de Rhodnius ecuadoriensis en la zona rural del Distrito de Cascas, Provincia Gran Chimú, La Libertad, Perú. Trujillo, 1999. (Tesis de Maestria en Ciencias, Mención Parasitologia - Universidad Nacional de Trujillo).

25. ROMAÑA, C.V.; RACINES, J.; AVILÉS, H. \& LEMA, F. - Observaciones de domiciliación de Rhodnius ecuadoriensis en focos endémicos de la Enfermedad de Chagas en el Ecuador. Microbiologia, 1: 59, 1994.

26. SCHENONE, H.; VILLAROEL, E.; ROJAS, A. \& CARRASCO, J. - Estudio comparativo del rendimiento de tres métodos de detección de la presencia de Triatoma infestans en viviendas infestadas Bol. chil. Parasit., 34: 7-12, 1979.

27. SCHOFIELD, C.J. - A comparison of sampling techniques for domestic populations of Triatominae. Trans. roy. Soc. trop. Med. Hyg., 72: 449-455, 1978.

28. TONN, R.J.; OTERO, M.A. \& JIMENEZ, J. - Comparación del método hora-hombre con la trampa Gómez-Núñez en la búsqueda de Rhodnius prolixus. Bol. Direcc. Malar., 16: 269-275, 1976.

29. VASQUEZ, J.E.; KRUSNELL, J.; ORN, A.; SOUSA, O.E. \& HARRIS, R.A. - Serological diagnosis of Trypanosoma rangeli infected patients. A comparison of different methods and its implications for the diagnosis of Chagas' disease. Scand. J. Immunol., 45: 322-330, 1997.

30. VEGA, S.I.; YON, C.; ESCURRA, C. et al. - Trypanosomiosis Americana en el distrito de Callayuc, Cajamarca, Perú. J. bras. Pat., 37 (4, supl.): 267, 2001.

31. WISNIVESKY-COLLI, C.; PAULONE, I.; PEREZ, A. et al. - A new tool for continuous detection of the presence of triatomine bugs, vectors of Chagas disease, in rural households. Medicina (B. Aires), 47: 45-50, 1987.

Received: 26 July 2002

Accepted: 10 February 2003 